\title{
Analysis on the Influence of Russian Historical Changes on Architectural Style
}

\author{
Guizhou Industry Polytechnic College, Guiyang 550025 \\ Guizhou Equipment manufacturing vocational college, Guiyang 550025
}

\section{Introduction}

Being restricted by the politics, society, economy, building materials and building technology of the times and influenced by architectural design ideas, viewpoints and artistic accomplishments, different architectural styles differ from each other in the floor plan, conformation structure, artistic treatment and manipulation and other aspects. For example, from $476 \mathrm{AD}$, the medieval Western pillar-type Greek architectural style, the delicate and fiddly rococo architecture style in the late period of Renaissance, the strictly symmetrical and prioritized architectural style in ancient China and other styles have political, artistic and economic nature of the times and clear historical and cultural traces. And this paper aims to find out different architectural styles in every period in accordance with Russia's historical changes.

\section{Byzantine Architectures} in the period of Kievan Rus Principality

1.1 Political and cultural characteristics of Kievan Rus Principality

[1] Kievan Rus is the earliest monarchy in Russia, and it also can be said to be the predecessor of the current Russia, the Ukraine and the Belarus. A.D. 980-1015 was the heyday of Kievan Rus, and the ruler of the period was Vladimir I Archduke, who unified the national power and established a strong state through the unifi- cation of faith, and since on Eastern Orthodoxy became the national religion of Kievan Rus. The Eastern Orthodoxy came from neighbor Byzantine Empire, and the Byzantine culture, with the introduction of the Eastern Orthodoxy into the culture of Rus, had changed into the original Russian culture and influenced all aspects of social life and economic culture, among which the most obvious one is that Byzantine-style Russian architecture style has become a typical building group at that time.

\subsection{Characteristics of Byzantine-} style Russian architecture

[2] The Byzantine Empire was the Eastern Roman Empire, and its architectural style mainly featured a large dome in its appearance which is situated on a square pillar similar to a cross, and similar to an onion from a distance. The interior of Byzantine buildings had very strong religious overtones. The walls were covered by colorful marble, and characters in religious stories on the arches and domes were inlaid with translucent small stained glass, and the optical principle was used in mosaic technology to tilt the glass in different directions to create a colorful flash effect.

Kievan Rus 's first typical Byzantine architecture was the Hagia Sophia located in Kiev, built in the year 1037 . The church had a total of six domes, with five silver ones surrounding with a high golden one, making the whole complex look sedate, mature and grand and embody-

\begin{abstract}
Russian architectural style is deeply influenced by historical changes and impelled by religious and cultural forces. After historical periods of Kievan Rus, Russian Tsar, the Soviet period, Russian Federation, different architectural styles such as European ancient architecture, Russian-style ancient architecture, Sovietstyle modern architecture are formed, becoming a unique Russian architectural group and world-renowned.
\end{abstract}

Key words: sponge city; urban planning

Published online: 30th Sept, 2017

ing a God-centered, solemn, elegant, and noble atmosphere. What's more, the Huaxili Buraren Church on the Red Square in Russia was also a famous Byzantine church building. The building materials and construction techniques of Byzantine structures have been developed from the earliest wooden buildings in Russia to highly skilled masonry buildings.

In the September 1223, the Mongol Empire invaded Russia, and from 1240 until 1480, Russia was ruled by Mongols and known as the Golden Horde. The 240-year rule left Russia's economic culture far behind Western Europe, so Russia's architectural style did not innovate during this period. 


\section{Baroque architecture and Rococo architectural decora- tion art in the era of the Russian Empire}

2.1Political and cultural characteristics in Tsarist Russia era

In 1721, Russian Empire (Russia or Tsarist Russia), the last monarchy in Russian history was established, which lasted nearly 200 years ${ }^{1}$. The Russian Empire has developed into the political, economic, cultural and religious center of north-east Rus and become an independent centra-lized state. In the $19^{\text {th }}$ century, Russia reached its all-time peak and became one of the world's powers.

One of the most representative rulers of this period is the Tsar Peter I and Catherine II. They moved the focus of national development west to neighbor European countries and made it easy to accept the civilization of Europe. In the architectural style, the pursuit of luxury and magnificent style promoted a new art idea of the architectural style in Russian Empire, and Baroque architecture and rococo architecture art met the aesthetic needs of the pompous and exclusive style in the Tsar era.

2.2 Characteristics of Baroque and Rococo architecture style

[3] In the late Middle Ages, the cultural renaissance movement in Europe pursued the maximal liberation of spirit and opposed the rigid thought, and in this background, Baroque architec-ture style with free and un-restrained style was generated ${ }^{2}$. Baroque architectural style formed its unique features with

strong color contrast, exquisite decorations and carvings, as well as the continuous art treasures on the domes and walls. In appearance, the front of the Baroque building was built with a wide array of columns, pilaster and unique shaped decorations.

Built in 1754-1762 and designed by the famous Italian architect
Rastrelli, the Winter Palace in St Petersburg is a typical Baroque architecture and was used to be the Russian Tsar's palace. The Winter Palace is exquisite and dazzling, and the majestic palace is surrounded by two rows of colonnades.

In order to make the Baroque architecture more beautiful, gorgeous and complicated rococo architecture came into being, and Rococo style in fact belongs to interior decoration $\mathrm{art}^{3}$. The Rococo style pursues decorations with bright and elegant colors, and also emphasizes on the exquisite and cumbersome technology. Its is delicate and gentle and asymmetric methods are often used, such as the use of arc and Sshaped lines, arc surfaces that connect the ceiling and walls, and murals at the corner. This style plays an important role in opposing rigid classical form, pursuing free and unrestrained style and expressing secular taste.

The interior decoration of the The Place and Park Enseble Tsarskoye Selo, built by Queen Ekaterina II, is a typical Rococo style, with exquisite palaces, fresh and soft colors, and a soft and charming vision. Tall marble pillars, long corridors, giant chandeliers, murals on roofs, statues located everywhere, gardens with exquisite roofs, and so on had jointly constituted the magnificent and majestic royal temples. Baroque building materials break through the simple stone

masonry technology and use the technology of wood and brick mixed structure, while rococo decorations use precious stones and strange materials as far as possible. For example, the Rococo decorative style in the Winter Palace consumes huge amounts of malachite, jasper, agate, honey wax and other materials.

\section{Constructivism architec- ture in the Soviet-era}

3.1Political and cultural characteristics in the Soviet-era
On November 7, 1917, the Tsar Empire was overthrown, the Russian Soviet Union Socialist Republic (USSR) was established, and the Communist society became the belief in the Soviet Union, promoting new culture revolutions and progressive cultural and artistic movements that provided the opportunity for practice of constructivism in arts, architecture, and design and other aspects, and spurring further development from Russian modernist architectural style to constructivism architec-tural style.

3.2 Characteristics of constructivism architectural style

The constructivism architecture of the Soviet Union combines advanced technology, engineer-ing and Communist belief, starts with structures, expresses the structural idea of the great unification by using rational architectural space structure, and explores the relationship between the structure techno-logy and function.

The first representative works of the constructivism architecture in Soviet Union is the program of the Third International Tower, which totally embodies the concept of constructivism. The appearance of the tower symbolizes the proletariat and communism and many institu-tions like the International Conference Center are included in it. Its symbolic meaning is more important than utility.

\section{Empire style architec-ture in Soviet times}

4.1Political and cultural characteristics in the Stalin's Era Stalin was a very representative leader of the Soviet period. Because of his autocratic style and forceful means, the latter called the period under his leadership as Stalin's era. This is a period of high economic development of Soviet Union, and during the period, industrialization, collectivization of agriculture, fiveyear plan, counter-revolutionary movement and other governance 
4.2 measures have been implemented, but due to excessive concentration and excessive centralization of power, the danger of disintegration of Soviet Union was buried. During Stalin's era, his political ideas and ruling methods were fully embodied in military, economic, cultural and indus-trial fields, and a number of skyscrapers of this period had a distinctive imperial architectural style.

\subsection{Characteristics of empire style} architecture

In the 20th century 40 to 50 , the "Stalinist style of empire" occupied the dominant position of Soviet architecture $^{4}$. Stalin-style architecture has a strong ideological characteristic and obvious pursuit of great, tower-ing and holy God. The building must have pillars, arches, staircases, large windows and huge doors to show the passion and invincible momentum of Communism. Stalin-style imperial buildings are generally magnificent, towering and symmetrical, and this style referred to Gothic architecture to a great extent, but differed from the Baroque style and rococo style of the Tsarist era. Seven high-rise buildings, including the University of Moscow, are great examples of this style.

\section{Architectural style in the transition period of the Russian Federation}

The Soviet Union disintegrated in 1991 and Russia entered a period of social transition. In the early stage of the transition, because of the turbulence in politic and economy, the architectural style entered into a diverse and disorderly explo-ration phase. With the develop-ment of Russia's commercial economy, architectural creation took the building of commercial buildings as the main part, so a large number of commercial buildings with varied styles and bright colors brought vigor to the drab and gloomy city image of the Soviet period.
Since entering 21th century, Russia's politic tends to be stable and the economy enters into the recovery period of multipolar development. The diversified development of social life has put forward new requirements for the culture and aesthetics of architecture, and various architectural conce-pts, such as classicism, eclectic and postmodernism architec-tural style, have formed a collision, thus making the Russian architectural style more diversified in later transition period. Zenith football stadium in San Pietro, locomotive stadium, and indoor speed skating center are all represen-tative buildings of this period.

Throughout the development of Russian architecture, the cla-ssical architectural style has always been accompanied with the development of the Russian architecture, and the pursuit of classic architectural aesthetics has praised the law of formal beauty. A set of perfect paradigm was formed by the proportion, composition, colu-mn, form and other elements and became the foundation of Russian traditional architecture for forming the characteristics of Russian architectural style.

And after the exploration in the transformation period, the modern New Russia has been divorced from the "power"-

oriented architectural style and gradually makes the property of the building return, and the development of architectural style gradually becomes more open from the independent closure.

\section{Conclusion}

[4] In the 1200-year history of Russia, culture and art have always been the soul of the nation, and the rulers of the past dynasties have built the architecture as the carrier of thought, culture and art and manifested the ideological consciousness and the cultural pursuit of the period in the structure and decoration of the building. The palace archi-tecture of the Tsar era embodied the taste of aristoc-ratic life, and were extremely exquisite and luxurious; Stalin embodied his flaunty and intrepid personalities and the invincible will of socialism in tall and sturdy buildings; modern Russia became pragmatic after the disintegration of the Soviet Union, and modern high-rise buildings were built on the land of Moscow. Therefore, the outstanding building not only has the utility, but also can bring people a sense of history, just as the Russian construction bears the 1200-year Russian history civilization.

\section{References}

[1] A Brief history of Russia [M]. Beijing Industrial University Press, 2017,05.

[2] Architecture a Spotter's Guide Classical Tempples to Soaring Skyscrapers [M]. China Machine Press, 2015,01.

[3] Yang Yuming. Analysis of Russian Architectural Style [J]. literature and art, 2013,08.

[4] Zhu Yanxu. Characteristics and Causes of New Architectural Style in Russia [J]. Architetural Design Management, 2005,01. 